http:/www.journals.zu.edu.eg/journalDisplay.aspx?Journalld=1\&queryType=Master $\quad$ Plant Production Science

\title{
EFFECT OF MINERAL NITROGEN FERTILIZER AND CULTURE MEDIA ON EGGPLANT TRANSPLANTS PRODUCTION
}

\author{
Moustafa H.A. Shehata*, M.A.I. Khalil, H.M. Arisha and A.A.M. Mohsen \\ Hort. Dept., Fac. Agric., Zagazig Univ., Egypt
}

Received: 06/11/2017 ; Accepted: 26/11/2017

\begin{abstract}
The present work was done in a private nursery under plastic houses conditions in Belbeis District, Sharkia Governorate (Egypt), during 2014 and 2015 seasons to study the effect of two mineral nitrogen fertilizer treatments and six culture media on seed germination (\%), vegetative growth characters, fresh and dry weights, growth analyses and chemical composition of eggplant transplants at 60 days from seed sowing. The obtained results showed that, the maximum values of seed germination (\%) were recorded by without application of mineral nitrogen fertilizer and using the culture media treatment of peat moss: vermiculite: compost at a ratio of 2:1:0 $(\mathrm{V} / \mathrm{V} / \mathrm{V})$, respectively in the first season and at a ratio of 1:1:0 and/or 3:1:0 $(V / V / V)$ in the second season. In addition, all tested fertilizer treatments did not caused any significant effect on all parameters of studied growth characters, except the dry weight of shoots in the first season only, were recorded the highest value by application of mineral nitrogen fertilizer. On the other hand, using the culture media which contained peat moss: vermiculite: compost at a ratio of 3:1:1 $(\mathrm{V} / \mathrm{V} / \mathrm{V})$, respectively recorded the maximum increment in fresh weight of parts and total fresh weight of whole transplant and had a significant effect on studied fresh weight ratio (FWR), root/plant dry weight ratio $(\mathrm{Rw} / \mathrm{Pw})$ characters, as well as on the potassium percentage in the tissue of transplants. The interaction between the culture media contained of peat moss: vermiculite: compost at a ratio of 3:1:0 $(\mathrm{V} / \mathrm{V} / \mathrm{V})$, respectively with application of mineral nitrogen fertilizer was the superior interaction treatment which had significantly effect on $\mathrm{N}, \mathrm{P}, \mathrm{K}$ and total carbohydrates contents in eggplant transplants, as well as dry weight of different parts of transplant in the second season only.
\end{abstract}

Key words: Egg plant, transplants, culture media, fertilizer, germination, dry/ fresh weight, growth analyses.

\section{INTRODUCTION}

Eggplant (Solanum melongena var. esculenta), belongs to family Solanaceae considered one of the most important summer vegetable crops cultivated in Egypt and a lot of countries around the world for their local consumption, processing and exportation. The total cultivated area of eggplant in Egypt was about 110,079 faddan, during 2013/2014 season which produced 1, 246, 642 million tons with average of 11, 3 tons/fad., (Statistics of the Ministry of Agriculture, 2014).

Yet, the cultivated area and total production of these crops increased by the time. Nurseries which using in the production of various

\footnotetext{
* Corresponding author: Tel. : +201064042423

E-mail address: mostafahussien458@gmail.com
}

vegetable transplants in different forms such as in plastic houses or net houses have a pronounced influence on quality of seedlings growth and development in the field, as well as on the marketable yield of many vegetable crops.

Transplants production is an important step in the horticultural production system, because its influence on the final crop yield. Culture media is a major factor that influencing on seeds germination, seeds emergence, growth and quality of transplants in a nursery (Unal, 2013). Moreover, the quality of the culture media used in transplants production is largely influenced by its physical, chemical and biological properties (Herrera et al., 2008). Culture media 
is not only a place where seeds are sown and transplants raised, but it is also a source and reservoir of plant nutrients (Indriyani et al., 2011). It is also anchors the root system and therefore supports of the plant (Abad et al., 2005). A good culture media should be composed of mixtures that are tender enough for seeds to easily germinate, retains moisture, drains excessive water and provide sufficient plant nutrients for transplants growth and development (Olaria et al., 2016).

In addition, compost holds water wall, provides the culture media with nutrients and can be made right on the farm. Peat moss and vermiculite mixes have been popular for production of many crops transplants, but the high cost of these components stimulated a search for substitutes. In this connection, Reis and Coelho (2007) studied the effect of mixing compost with peat to prepare substrates for the production of vegetable transplants. Sewage sludge, municipal solid waste and yard prunings were mixed at the proportions $(V / V)$ of $1: 0: 3$; $0: 1: 1.5$ and $1: 1: 2$, respectively on tomato. The emergence of transplants was not affected and reduced in compost mixes. Liptay et al. (1982) found that mixture of shredded sphagnum peat moss and vermiculite $(1: 1)$ with nutrient were added, and gave rapid emergence in tomato seeds.

Therefore, the objective of this work was to determine the best components of the transplants culture media and their ratios in the nurseries for growing eggplant transplants and with or without application of mineral nitrogen fertilizer, on the production of eggplant transplants.

\section{MATERIALS AND METHODS}

This work was carried out during the two successive seasons of 2014 and 2015 in a private nursery under plastic house conditions, in Belbeis District, Sharkia Governorate (Egypt), to study the effect of application mineral nitrogen, without application of mineral nitrogen fertilizer and the culture media on seed germination (\%), vegetative growth characters, fresh and dry weights, growth analyses and chemical composition of eggplant transplants during 2014 and 2015 seasons.
The experiment included 12 treatments, which were the combinations between two mineral nitrogen fertilizer and six culture media as follows:

\section{Fertilizer Treatments}

1) Without application of mineral nitrogen fertilizer.

2) With application of mineral nitrogen fertilizer.

\section{Culture Media}

1) Peat moss: Vermiculite: Compost $(1: 1: 0 \mathrm{~V} / \mathrm{V} / \mathrm{V})$

2) Peat moss: Vermiculite: Compost $(2: 1: 0 \mathrm{~V} / \mathrm{V} / \mathrm{V})$

3) Peat moss: Vermiculite: Compost (3:1:0 V/V/V)

4) Peat moss: Vermiculite: Compost $(1: 1: 1 \mathrm{~V} / V / V)$

5) Peat moss: Vermiculite: Compost $(2: 1: 1 \mathrm{~V} / \mathrm{V} / \mathrm{V})$

6) Peat moss: Vermiculite: Compost (3:1:1 $V / V / V)$

These treatments were arranged in a split plot design system with three replicates. Fertilizer treatments were randomly arranged in the main plots, while the culture media were randomly distributed in the sub plots. Every replicate contained nine trays ( 3 every treatment). In addition, every speedling tray contained 209 eyes.

In this experiment, ammonium nitrate $(33.5 \%$ N) was used as a source of mineral nitrogen fertilizer (added to the culture media which prepared according to the distributed treatments).

Calcium super phosphate $\left(15.5 \% \mathrm{P}_{2} \mathrm{O}_{5}\right)$ and potassium sulphate $\left(48 \% \mathrm{~K}_{2} \mathrm{O}\right)$ were used as a source of $\mathrm{P}$ and $\mathrm{K}$ fertilizers, respectively (recommended doses of every one presented in Table 1 and added in the preparation of the culture media before seed sowing in the speedling trays to all treatments. In addition, magnesium sulphate and micronutrients elements also added as recommended to the culture media which prepared.

\section{Preparation of Speedling Trays}

The speedling trays were full by the different ratio of the culture media as ratio as described above. Eggplant seeds (Balady cv.) were sown in speedling trays on 15 June and 10 October in 2014 and 2015 seasons, respectively. After sowing, the speedling trays were incubated in the incubation room for one week. After then, all speedling trays were putted on the benches under the plastic house. 
In addition, the recommended used fertilizers were added as nutrient solutions to the culture media in the speedling trays weekly during the growing season of eggplant transplants as shown in (Table 1).

The other normal agricultural treatments for growing eggplant transplants production, except fertilization were practiced.

\section{Data Recorded}

The recorded data were as follows:

\section{Seed germination (\%)}

Seed germination percentage was calculated according to the following formula:

Germination percentage $=$

Number of germinated seeds

Number of total seeds

Vegetative growth characters of transplants

A random sample of ten transplants from each experimental unit (in the three replicates) were randomly taken at 60 days from sowing and the following data were determined:

\section{Morphological characters}

A) Average root length $(\mathrm{cm})$.

B) Average stem length (cm).

C) Average number of leaves /transplant.

Fresh weight of transplants (g) during 2015 season

A) Average fresh weight of root.

B) Average fresh weight of shoot (stem+ leaves).

C) Total fresh weight of transplant (whole transplant).

\section{Dry weight of transplants (g)}

Different parts of transplants, i.e., roots, stem and leaves were dried at $70^{\circ} \mathrm{C}$ till constant weight and the following data were recorded:

A) Average dry weight of root.

B) Average dry weight of shoot (stem+ leaves).

C) Total dry weight of transplant (whole transplant).

\section{Growth analyses during 2015 season}

All growth analyses characters were determined according to the formulas as described by Radford (1967) as follows:
Fresh/ dry weight ratio (FWR)

$$
F W R=\frac{F W}{W}
$$

Where:

FW: Fresh weight per plant (g)

W: Dry weight per plant (g)

Shoot/ Root dry weight ratio (SW/RW)

$$
\mathrm{S}_{\mathrm{W}} / \mathrm{R}_{\mathrm{W}}=\frac{\mathrm{S}_{\mathrm{W}}}{\mathrm{R}_{\mathrm{W}}}
$$

Where:

$\mathrm{S}_{\mathrm{W}}$ : Shoot dry weight $(\mathrm{g})$

$\mathrm{R}_{\mathrm{W}}$ : Root dry weight $(\mathrm{g})$

Root/ Plant dry weight ratio (RW/PW)

$$
\mathrm{R}_{\mathrm{W}} / \mathrm{P}_{\mathrm{W}}=\frac{\mathrm{R}_{\mathrm{W}}}{\mathrm{P}_{\mathrm{W}}}
$$

Where:

$\mathrm{R}_{\mathrm{W}}$ : Roots dry weight (g)

$\mathrm{P}_{\mathrm{W}}$ : Plant dry weight $(\mathrm{g})$

All mentioned growth analyses measurements were calculated at 60 days from seed sowing in the second season only.

\section{Chemical Composition of Transplants}

The dry weight of shoots were finely ground and wet digested with sulfuric acid and perchloric acid (3:1, respectively). Nitrogen, phosphorus and potassium were determined as dry weight basis according to the methods described by Bremner and Mulvaney (1982), Olsen et al. (1982) and Jackson (1970), respectively. Moreover, total carbohydrates in dry shoot (stem + leaves) were determined according to the method described by Dubois $\boldsymbol{e t}$ al. (1956).

\section{Statistical Analysis}

The obtained data were subjected to the analysis of variance according to Snedecor and Cochran (1980). Mean separation was done by Duncan (1958). 
Table 1. The recommended dose of chemical fertilizers which added to the speedling trays during the two growing seasons of eggplant transplants

\begin{tabular}{|c|c|}
\hline$\overline{\text { Chemical fertilizers }}$ & Quantity \\
\hline Peat moss & Package $(50 \mathrm{~kg})$ \\
\hline Vermiculite & Package $(50 \mathrm{~kg})$ \\
\hline Ammonium nitrate $(33.5 \% \mathrm{~N})$ & $400 \mathrm{~g}$ \\
\hline Calcium super phosphate $\left(15.5 \% \mathrm{P}_{2} \mathrm{O}_{5}\right)$ & $500 \mathrm{~g}$ \\
\hline Potassium sulphate $\left(48 \% \mathrm{~K}_{2} \mathrm{O}\right)$ & $300 \mathrm{~g}$ \\
\hline Magnesium sulphate $\mathrm{Mg} \mathrm{SO}_{4}$ & $30 \mathrm{~g}$ \\
\hline Micronutrients elements Fe, Mn and $\mathrm{Zn}(20 / 20 / 20)$ & $80 \mathrm{~g}$ \\
\hline Tiles powder & $4 \mathrm{~kg}$ \\
\hline
\end{tabular}

\section{RESULTS AND DISCUSSION}

\section{Seed Germination (\%)}

\section{Effect of mineral nitrogen fertilizer}

The highest values of seed germination (\%) were recorded via the treatment of without application of mineral nitrogen fertilizer in the first season only (Table 2).

On the contrary, all treatments under study did not reflect any significant effect on seed germination $(\%)$ in the second season.

\section{Effect of the culture media}

It is quite clear from results in Table 3 that, all treatments of the culture media exerted a marked and significant effect on the germination percentage of eggplant seeds, while the maximum values in this respect were obtained via using the culture media which contained of peat moss + vermiculite + compost at a ratio of 1:1:0 and/or 2:1:0, respectively without significant differences between them in the two investigated seasons. These results may be due to the good balance between water content and the aeration of these media.

On the contrary, the lowest values of eggplant seed germination were recorded by using the culture media which contained peat moss + vermiculite + compost at a ratio of 1:1:1, respectively. These results were holding true in both seasons of the study.

These results are going in agreement with those reported by Liptay et al. (1982), ElBeltagy et al. (1986), Kampf and Jung (1991), Neamati et al. (2010), Rakesh and Adarsh (2010) and Mathowa et al. (2016) on tomato, they found that different culture media caused different responses on its seed germination.

\section{Effect of the interaction}

It is quite clear from the presented results in Table 4 that, the maximum values of eggplant seed germination (\%) were recorded by without application of mineral nitrogen fertilizer and the culture media of peat moss + vermiculite + compost at a ratio of $2: 1: 0$, respectively in the first season. While, such fertilizer treatment combined with the culture media of peat moss + vermiculite + compost at a ratio of 1:1:0 and/or 3:1:0 $(V / V / V)$, respectively being the most effective and favorable treatments for increasing the percentage of eggplant seed germination (\%) in the second season.

Finally, from the foregoing results, it could be suggested that germination percentage of eggplant seeds significantly affected by the two factors of study, while such effect was fluctuated from season and from treatment to another. 
These results are in accordance with those reported by Augustinus (2007) on basil seeds germination percentage.

\section{Morphological Characters of Transplants}

\section{Effect of mineral nitrogen fertilizer}

The obtained results in Table 2 reveal that all tested treatments of mineral nitrogen fertilizer (with and /or without application) did not caused any significant effect on vegetative growth characters in both seasons of the study, i.e. root and stem lengths, as well as number of leaves per transplant.

These results are in harmony with those reported by Kokalis-Burelle et al. (2003) on muskmelon and watermelon transplants, Bi et al. (2008) on cucumber and tomato transplants and Ekinci et al. (2014) on cauliflower transplants, they concluded that nitrogen fertilizer did not effected any significant in vegetative growth of these crops.

\section{Effect of the culture media}

The presented results in Table 3 show that, in the first season, using the culture media of peat moss + vermiculite + compost at a ratio of $2: 1: 0$, respectively, recorded the maximum increments in root and stem length of eggplant transplants, while using the culture media which contained peat moss + vermiculite + compost at a ratio of 1:1:0, respectively, being the superior treatment for increasing number of leaves per transplant.

Moreover, in the second season, the highest value of root length was more distinct via using the culture media of peat moss + vermiculite + compost at a ratio of $3: 1: 1$, respectively. On the other hand, the maximum value of stem length was more achieved by using the culture media of peat moss + vermiculite + compost at a ratio of 1:1:0 $(V / V / V)$, respectively. In addition, using the culture media of peat moss + vermiculite + compost at a ratio of 2:1:1 $(V / V / V)$, respectively came in the first rank for increasing number of leaves per transplant in the second season only.

From the above mentioned results, it could be concluded that, the effect of all tested culture media on the vegetative growth characters of eggplant transplants was varied greatly according to their used ratio.
These results are in accordance with those reported by Hoza (2000) on eggplant, Botrini et al. (2006), Hashemimajd et al. (2006), Badran et al. (2007) on tomato and Soliman (2010) on eggplant, Rahimi et al. (2013) and Gama et al. (2015) on tomato transplants, came to similar conclusion.

\section{Effect of the interaction}

It is quite clear from the presented results in Table 4 that, the two factors of study (mineral nitrogen fertilizer and the culture media) reflected a marked effect on the vegetative growth characters of eggplant transplants at 60 days from seed sowing in the two investigated seasons. In this regard, in the first season, the mixture peat moss + vermiculite + compost at a ratio of 2:1:0, respectively, without application of mineral nitrogen fertilizer being the most effective treatment and recorded the maximum values of both root length and number of leaves per transplant. While, using the culture media treatment of peat moss + vermiculite + compost at a ratio of $3: 1: 0$, respectively, with application of mineral nitrogen fertilizer being the superior one for increasing stem length of eggplant transplants.

Furthermore, in the second season, it is evident from such results in Table 4 that, the interaction treatment between without application of mineral nitrogen fertilizer the mixture peat moss + vermiculite + compost at a ratio of $3: 1: 1$, $1: 1: 0$ and $3: 1: 0$, respectively recorded the maximum value of root length, stem length and number of leaves per transplant.

From the above mentioned results, it could be suggested that the effect of the two factors of study (the culture media and mineral nitrogen fertilizer) varied greatly from treatment and from season to another.

These results are going in agreement with those obtained by Arenas et al. (2002) on tomato transplant, they reported that the different culture media and nitrogen fertilizer gave a different increases responded on vegetative growth of tomato transplants.

\section{Fresh Weight of Transplants}

\section{Effect of mineral nitrogen fertilizer}

It is quite clear from the presented results in Table 5 that, application or without application of mineral nitrogen fertilizer to the culture 
Table 2. Effect of mineral nitrogen fertilizer on the germination percentage of eggplant seeds and the morphological characters of eggplant transplants at 60 days from seed sowing during 2014 and 2015 seasons

\begin{tabular}{lcccc}
\hline Mineral nitrogen fertilizer & $\begin{array}{c}\text { Seed } \\
\text { germination } \\
(\mathbf{\%})\end{array}$ & $\begin{array}{c}\text { Moot length } \\
(\mathbf{c m})\end{array}$ & $\begin{array}{c}\text { Stem length } \\
(\mathbf{c m})\end{array}$ & $\begin{array}{c}\text { Number of } \\
\text { leaves }\end{array}$ \\
\hline Without application & & & $\mathbf{2 0 1 4}$ season \\
With application & 74.53 & 5.71 & 5.69 & 2.48 \\
LSD (0.05) & 70.66 & 5.23 & 6.20 & 2.47 \\
& 2.09 & NS & NS & NS \\
Without application & & & $\mathbf{2 0 1 5}$ season & \\
With application & 72.05 & 6.62 & 5.00 & 3.61 \\
LSD (0.05) & 59.41 & 6.47 & 4.62 & 3.50 \\
\hline
\end{tabular}

NS = Not significant

Table 3. Effect of the culture media on the germination percentage of eggplant seeds and the morphological characters of eggplant transplants at 60 days from seed sowing during 2014 and 2015 seasons

\begin{tabular}{|c|c|c|c|c|}
\hline \multirow{2}{*}{$\begin{array}{l}\text { Culture media } \\
\text { Peat moss :Vermiculite :Compost }(V / V / V)\end{array}$} & \multirow{2}{*}{$\begin{array}{c}\text { Seed } \\
\text { germination } \\
(\%)\end{array}$} & \multicolumn{3}{|c|}{ Morphological character } \\
\hline & & $\begin{array}{l}\text { Root length } \\
\text { (cm) }\end{array}$ & $\begin{array}{l}\text { Stem length } \\
\text { (cm) }\end{array}$ & $\begin{array}{c}\text { Number of } \\
\text { leaves }\end{array}$ \\
\hline & \multicolumn{4}{|c|}{2014 season } \\
\hline 1:1:0 & 79.11 & 6.49 & 5.51 & 2.48 \\
\hline 2:1:0 & 78.86 & 7.53 & 6.78 & 2.47 \\
\hline 3:1:0 & 75.50 & 6.72 & 6.70 & 2.33 \\
\hline 1:1:1 & 63.15 & 4.05 & 6.25 & 2.07 \\
\hline 2:1:1 & 65.94 & 3.27 & 6.05 & 2.05 \\
\hline 3:1:1 & 72.96 & 4.78 & 4.37 & 2.37 \\
\hline \multirow[t]{2}{*}{ LSD (0.05) } & 8.06 & 0.80 & 1.24 & 0.32 \\
\hline & \multicolumn{4}{|c|}{2015 season } \\
\hline 1:1:0 & 73.85 & 6.75 & 5.28 & 3.15 \\
\hline 2:1:0 & 75.76 & 6.40 & 4.38 & 3.50 \\
\hline 3:1:0 & 69.63 & 6.63 & 4.52 & 3.70 \\
\hline 1:1:1 & 55.36 & 6.39 & 4.65 & 3.70 \\
\hline 2:1:1 & 58.40 & 6.28 & 4.80 & 3.83 \\
\hline 3:1:1 & 61.34 & 6.85 & 5.22 & 3.48 \\
\hline LSD (0.05) & 10.02 & 0.27 & 0.58 & 0.34 \\
\hline
\end{tabular}


Table 4. Effect of the interaction between mineral nitrogen fertilizer and the culture media on the germination percentage of eggplant seeds and the morphological characters of eggplant transplants at 60 days from seed sowing during 2014 and 2015 seasons

\begin{tabular}{|c|c|c|c|c|c|c|}
\hline \multirow[t]{2}{*}{ Mineral nitrogen fertilizer } & \multirow{2}{*}{$\begin{array}{c}\text { Culture media } \\
\text { Peat moss: Vermiculite } \\
\text { Compost }(V / V / V)\end{array}$} & \multirow{2}{*}{\multicolumn{2}{|c|}{$\begin{array}{c}\text { Seed } \\
\text { germination } \\
(\%)\end{array}$}} & \multicolumn{3}{|c|}{ Morphological character } \\
\hline & & & & $\begin{array}{l}\text { Root } \\
\text { length } \\
\text { (cm) }\end{array}$ & $\begin{array}{c}\text { Stem } \\
\text { length } \\
(\mathrm{cm})\end{array}$ & $\begin{array}{c}\text { Number } \\
\text { of } \\
\text { leaves } \\
\end{array}$ \\
\hline \multirow{8}{*}{ Without application } & & \multicolumn{5}{|c|}{2014 season } \\
\hline & 1:1:0 & \multicolumn{2}{|c|}{79.70} & 6.88 & 5.22 & 2.47 \\
\hline & 2:1:0 & \multicolumn{2}{|c|}{87.56} & 8.42 & 6.55 & 2.83 \\
\hline & 3:1:0 & \multicolumn{2}{|c|}{74.16} & 6.57 & 6.27 & 2.20 \\
\hline & 1:1:1 & \multicolumn{2}{|c|}{61.88} & 3.90 & 6.70 & 2.07 \\
\hline & 2:1:1 & \multicolumn{2}{|c|}{64.91} & 3.00 & 5.77 & 2.13 \\
\hline & 3:1:1 & \multicolumn{2}{|c|}{78.94} & 5.50 & 3.60 & 2.60 \\
\hline & 1:1:0 & \multicolumn{2}{|c|}{78.52} & 6.10 & 5.80 & 2.50 \\
\hline \multirow{4}{*}{ With application } & 2:1:0 & \multicolumn{2}{|c|}{70.17} & 6.63 & 7.00 & 2.10 \\
\hline & 3:1:0 & \multicolumn{2}{|c|}{76.85} & 6.87 & 7.13 & 2.47 \\
\hline & 1:1:1 & \multicolumn{2}{|c|}{64.43} & 4.20 & 5.80 & 2.07 \\
\hline & $2: 1: 1$ & \multicolumn{2}{|c|}{66.98} & 3.53 & 6.33 & 1.97 \\
\hline \multirow{3}{*}{ LSD (0.05) } & 3:1:1 & 66.9 & & 4.07 & 5.13 & 2.13 \\
\hline & & 11.4 & & 1.13 & 1.75 & 0.46 \\
\hline & & & & 2015 sea & son & \\
\hline & 1:1:0 & 78.87 & 6.68 & & 35 & 3.20 \\
\hline & 2:1:0 & 77.12 & 6.35 & & 28 & 3.53 \\
\hline Wvil & 3:1:0 & 78.87 & 6.68 & & 18 & 4.13 \\
\hline Pitiont appication & 1:1:1 & 54.17 & 6.78 & & 03 & 3.96 \\
\hline & 2:1:1 & 65.49 & 6.25 & & 08 & 3.60 \\
\hline & 3:1:1 & 77.76 & 7.02 & & 06 & 3.26 \\
\hline & 1:1:0 & 68.83 & 6.83 & & 22 & 3.10 \\
\hline & 2:1:0 & 74.41 & 6.45 & & 48 & 3.46 \\
\hline $\mathbf{w}$ & 3:1:0 & 60.39 & 6.58 & & 86 & 3.26 \\
\hline 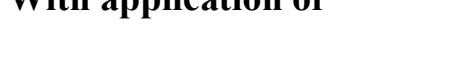 & 1:1:1 & 56.56 & 6.00 & & 26 & 3.43 \\
\hline & 2:1:1 & 51.31 & 6.30 & & 52 & 4.06 \\
\hline & 3:1:1 & 44.93 & 6.68 & & 38 & 3.70 \\
\hline LSD (0.05) & & 14.16 & 0.39 & & 82 & 0.48 \\
\hline
\end{tabular}


Table 5. Effect of mineral nitrogen fertilizer on the fresh weight (g) of eggplant transplants at 60 days from seed sowing during 2015 season

\begin{tabular}{lccc}
\hline Mineral nitrogen fertilizer & \multicolumn{3}{c}{ Fresh weight (g) } \\
\cline { 2 - 4 } & Root & $\begin{array}{c}\text { Shoot } \\
\text { (stem+ leaves) }\end{array}$ & Total \\
\hline Without application & 0.50 & 0.99 & 1.49 \\
With application & 0.53 & 0.85 & 1.38 \\
LSD (0.05) & NS & NS & NS \\
\hline
\end{tabular}

$\mathrm{NS}=$ Not significant

media did not reflect any significant effect on the fresh weight of root, shoot (stem+ leaves) and whole eggplant transplant at 60 days from seed sowing during the second season (2015).

These results are in harmony with those reported by Kokalis-Burelle et al. (2003) on muskmelon and watermelon transplants, and Ekinci et al. (2014) on cauliflower transplants.

\section{Effect of the culture media}

The obtained results presented in Table 6 reveal that, the treatments of the culture media exerted a marked effect on the fresh weight of root, shoot (stem + leaves) and total fresh weight of whole transplant, while the maximum increment in this respect were more distinct via using the culture media treatment of peat moss + vermiculite + compost at a ratio of $3: 1: 1$, respectively as compared to the other treatments. The superior effect of these treatments may be due to the good physiological and biochemical processes in the transplant during the growing season.

These results are in accordance with those obtained by Shahinrokhsar and Tavusi (2008) on strawberry, Ikiz et al. (2009) on pepper and Peyvast et al. (2008) and Zandi et al. (2011) on cucumber transplants.

\section{Effect of the interaction}

From the obtained results presented in Table 7 it is evident that, the interaction treatments between the two factors of study, i.e. the culture media and mineral nitrogen fertilizer showed a significant effect on the fresh weight of eggplant transplants at 60 days from seed sowing during
2015 season. In addition, the interaction between the culture media of peat moss + vermiculite + compost at a ratio of $3: 1: 1$, respectively with application of mineral nitrogen fertilizer recorded the maximum value of root fresh weight. On the other hand, the combination between the culture media of peat moss + vermiculite + compost at a ratio of 1:1:1 and without application of mineral nitrogen fertilizer being the superior one for increasing the fresh weight of both shoot (stem + leaves) and whole eggplant transplants.

\section{Dry Weight of Transplants}

\section{Effect of mineral nitrogen fertilizer}

It is quite clear from the presented results in Table 8 that, all mineral nitrogen fertilizer treatments did not reflect any significant effect on the dry weight of root, shoot (stem + leaves) and whole eggplant transplant at 60 days from seed sowing in the two seasons of study, except the dry weight of shoot (stem + leaves) in the first season only which recorded the highest value by application of mineral nitrogen fertilizer.

These results are going in agreement with those reported by Ekinci et al. (2014) on cauliflower transplants and Angadi et al. (2017) on tomato transplants.

\section{Effect of the culture media}

Results in Table 9 reveal that, using the culture media treatment of peat moss + vermiculite + compost at a ratio of 1:1:0, respectively being the superior treatment for increasing the dry weight of root, shoot (stem + 
Table 6. Effect of the culture media on the fresh weight (g) of eggplant transplants at 60 days from seed sowing during 2015 season

\begin{tabular}{lccc}
\hline Culture media & \multicolumn{3}{c}{ Fresh weight $(\mathrm{g})$} \\
\cline { 2 - 4 } & Root & $\begin{array}{c}\text { Shoot } \\
\text { (stem+ leaves) }\end{array}$ & Total \\
Peat moss :Vermiculite :Compost $(V / V / V)$ & & 0.86 & 1.41 \\
\hline $\mathbf{1 : 1 : 0}$ & 0.55 & 0.64 & 0.93 \\
$\mathbf{2 : 1 : 0}$ & 0.29 & 0.99 & 1.56 \\
$\mathbf{3 : 1 : 0}$ & 0.57 & 0.95 & 1.40 \\
$\mathbf{1 : 1 : 1}$ & 0.44 & 1.04 & 1.53 \\
$\mathbf{2 : 1 : 1}$ & 0.49 & 1.08 & 1.80 \\
$\mathbf{3 : 1 : 1}$ & 0.72 & 0.23 & 0.21 \\
LSD (0.05) & 0.25 & & \\
\hline
\end{tabular}

Table 7. Effect of interaction between mineral nitrogen fertilizer and the culture media on the fresh weight (g) of eggplant transplants at 60 days from seed sowing during 2015 season

\begin{tabular}{|c|c|c|c|c|}
\hline \multirow[t]{2}{*}{ Mineral nitrogen fertilizer } & \multirow{2}{*}{$\begin{array}{c}\text { Culture media } \\
\text { Peat moss: Vermiculite: } \\
\text { Compost }(V / V / V)\end{array}$} & \multicolumn{3}{|c|}{ Fresh weight (g) } \\
\hline & & Root & $\begin{array}{c}\text { Shoot } \\
\text { (stem+ leaves) }\end{array}$ & Total \\
\hline \multirow{5}{*}{ Without application } & 1:1:0 & 0.45 & 0.85 & 1.30 \\
\hline & $2: 1: 0$ & 0.31 & 0.79 & 1.10 \\
\hline & 3:1:0 & 0.60 & 1.05 & 1.65 \\
\hline & 1:1:1 & 0.60 & 1.30 & 1.90 \\
\hline & 2:1:1 & 0.38 & 0.85 & 1.23 \\
\hline \multirow{7}{*}{ With application } & 3:1:1 & 0.67 & 1.16 & 1.83 \\
\hline & 1:1:0 & 0.66 & 0.87 & 1.53 \\
\hline & 2:1:0 & 0.27 & 0.49 & 0.76 \\
\hline & 3:1:0 & 0.55 & 0.92 & 1.47 \\
\hline & 1:1:1 & 0.29 & 0.60 & 0.89 \\
\hline & 2:1:1 & 0.60 & 1.24 & 1.84 \\
\hline & 3:1:1 & 0.77 & 1.01 & 1.78 \\
\hline LSD (0.05) & & 0.35 & 0.32 & 0.61 \\
\hline
\end{tabular}


Table 8. Effect of mineral nitrogen fertilizer on the dry weight (g) of eggplant transplants at 60 days from seed sowing during 2014 and 2015 seasons

\begin{tabular}{lccc}
\hline Mineral nitrogen fertilizer & \multicolumn{3}{c}{ Dry weight $(\mathrm{g})$} \\
\cline { 2 - 4 } & Root & $\begin{array}{c}\text { Shoot } \\
\text { (stem+ leaves) }\end{array}$ & Total \\
\hline Without application & 1.20 & 1.82 & 3.02 \\
With application & 1.39 & 1.99 & 3.38 \\
LSD (0.05) & $\mathrm{NS}$ & 0.08 & $\mathrm{NS}$ \\
& & $\mathbf{2 0 1 5}$ season & \\
Without application & 0.12 & 0.17 & 0.29 \\
With application & 0.15 & 0.17 & 0.32 \\
LSD (0.05) & $\mathrm{NS}$ & $\mathrm{NS}$ & $\mathrm{NS}$ \\
\hline NS $=$ Not significan & &
\end{tabular}

$\mathrm{NS}=$ Not significant

Table 9. Effect of the culture media on the dry weight (g) of eggplant transplants at 60 days from seed sowing during 2014 and 2015 seasons

\begin{tabular}{lccc}
\hline Culture media & \multicolumn{3}{c}{ Dry weight $(\mathbf{g})$} \\
\cline { 2 - 4 } Peat moss :Vermiculite :Compost $(\boldsymbol{V} / \boldsymbol{V} / \boldsymbol{V})$ & Root & $\begin{array}{c}\text { Shoot } \\
\text { (stem+ leaves) }\end{array}$ & Total \\
\hline & & $\mathbf{2 0 1 4}$ season \\
$\mathbf{1 : 1 : 0}$ & 1.88 & 2.48 & 4.37 \\
$\mathbf{2 : 1 : 0}$ & 1.47 & 1.88 & 3.35 \\
$\mathbf{3 : 1 : 0}$ & 1.60 & 2.08 & 3.68 \\
$\mathbf{1 : 1 : 1}$ & 1.08 & 1.83 & 2.92 \\
$\mathbf{2 : 1 : 1}$ & 0.88 & 1.77 & 2.65 \\
$\mathbf{3 : 1 : 1}$ & 0.85 & 1.38 & 2.23 \\
LSD $(\mathbf{0 . 0 5})$ & 0.33 & 0.42 & 0.68 \\
& & $\mathbf{2 0 1 5}$ season & \\
$\mathbf{1 : 1 : 0}$ & & 0.17 & 0.27 \\
$\mathbf{2 : 1 : 0}$ & 0.12 & 0.14 & 0.26 \\
$\mathbf{3 : 1 : 0}$ & 0.12 & 0.18 & 0.31 \\
$\mathbf{1 : 1 : 1}$ & 0.13 & 0.17 & 0.30 \\
$\mathbf{2 : 1 : 1}$ & 0.13 & 0.18 & 0.34 \\
$\mathbf{3 : 1 : 1}$ & 0.16 & 0.18 & 0.35 \\
LSD $(\mathbf{0 . 0 5})$ & 0.17 & 0.03 & 0.05 \\
\hline
\end{tabular}


leaves) and whole eggplant transplant in the first season. While, using the culture media of peat moss + vermiculite + compost at a ratio of $3: 1: 1$ $(V / V / V)$, respectively recorded the maximum value of characters as described above mentioned in the second one.

In this connection, Shahinrokhsar and Tavusi (2008) on strawberry transplants, Ikiz et al. (2009) on pepper transplants, Ghanbari and Aboutalebi (2009) on cucumber transplants and Soliman (2010) on eggplant and pepper transplants, Zandi et al. (2011) on cucumber transplants and Alam et al. (2014) on tomato transplants came to similar conclusion.

\section{Effect of the interaction}

It is obvious from the presented results in Table 10 that, application of mineral nitrogen fertilizer to the culture media treatment of peat moss + vermiculite + compost at a ratio of 1:1:0, respectively being the most effective treatment for recorded the maximum values of root, shoot (stem + leaves) and total dry weight of eggplant transplants at 60 days from seed sowing in the first season.

On the other hand, application of mineral nitrogen fertilizer to the culture media treatment of peat moss + vermiculite + compost at a ratio of $2: 1: 1,3: 1: 1$ and $3: 1: 0(V / V / V)$, respectively, recorded the highest increments on the dry weight of root, shoot (stem + leaves) and whole eggplant transplant, respectively without significant differences between them in the second season.

The obtained results are in accordance with those reported by Danaher et al. (2016) on tomato transplants.

From the foregoing results, it could be suggested that the interaction between mineral nitrogen fertilizer and the culture media exerted a significant effect on the dry weight of eggplant transplants in both seasons of the study.

\section{Growth Analyses of Transplants}

\section{Effect of mineral nitrogen fertilizer}

The presented results in Table 11 show the effect of mineral nitrogen fertilizers on the growth analyses of eggplant transplants at 60 days from seed sowing during 2015 season. It is evident from such results that, the fresh/dry weight ratio (FWR) and shoot/root dry weight ratio $(\mathrm{Sw} / \mathrm{Rw})$ characters significantly reduced by application of mineral nitrogen fertilizers to the culture media of eggplant transplants compared with application mineral nitrogen fertilizers treatment. While root/ plant dry weight ratio $(\mathrm{Rw} / \mathrm{Pw})$ character significantly increased by application of mineral nitrogen fertilizers in the culture media of eggplant transplants.

The obtained results are in line with those found by Ramteke et al. (2013) on Pisum sativum, Vigna radiant and Vigna catjang, and Sharaf-Eldin et al. (2015) on chinese cabbage transplants.

\section{Effect of the culture media}

Results in Table 12 indicate that, there were significant differences between the tested treatments on the growth analyses studied characters. The culture media treatment of peat moss + vermiculite + compost at a ratio of $3: 1: 1$ $(V / V / V)$, respectively came in the first rank and recorded significant effect on the fresh weight/ dry weight ratio (FWR) and root/ plant dry weight ratio $(\mathrm{Rw} / \mathrm{Pw})$, as compared with the other treatments in this respect. On the other hand, using the culture media treatment of peat moss + vermiculite + compost at a ratio of 1:1:1 $(V / V / V)$ recorded the maximum value of shoot/ root dry weight ratio $(\mathrm{Sw} / \mathrm{Rw})$ of eggplant transplants, as compared with the other study treatments.

The obtained results are in accordance with those reported by Rahimi et al. (2013) on tomato transplants.

\section{Effect of the interaction}

The presented results in Table 13 show the effect of the interaction treatments between the two factors of study (the culture media and mineral nitrogen fertilizer) on the growth analyses of eggplant transplants at 60 days from seed sowing during 2015 season. It is clear from such results that using the culture treatment of peat moss + vermiculite + compost at a ratio of 1:1:0 $(V / V / V)$, respectively without application of mineral nitrogen fertilizers was the best interaction treatment to reflected a significant effect on the fresh weight/dry weight ratio (FWR) 
Table 10. Effect of the interaction between mineral nitrogen fertilizer and the culture media on the dry weight (g) of eggplant transplants at 60 days from seed sowing during 2014 and 2015 seasons

\begin{tabular}{|c|c|c|c|c|}
\hline \multirow[t]{2}{*}{ Mineral nitrogen fertilizer } & \multirow{2}{*}{$\begin{array}{c}\text { Culture media } \\
\text { Peat moss : Vermiculite : } \\
\text { Compost }(V / V / V)\end{array}$} & \multicolumn{3}{|c|}{ Dry weight (g) } \\
\hline & & Root & $\begin{array}{l}\text { Shoot } \\
\text { m+ lea }\end{array}$ & Total \\
\hline \multirow{8}{*}{ Without application } & & \multicolumn{3}{|c|}{2014 season } \\
\hline & $1: 1: 0$ & 1.83 & 2.47 & 4.30 \\
\hline & $2: 1: 0$ & 1.57 & 1.83 & 3.40 \\
\hline & $3: 1: 0$ & 1.23 & 1.97 & 3.20 \\
\hline & 1:1:1 & 1.17 & 1.86 & 3.03 \\
\hline & $2: 1: 1$ & 0.77 & 1.53 & 2.30 \\
\hline & 3:1:1 & 0.63 & 1.27 & 1.90 \\
\hline & $1: 1: 0$ & 1.93 & 2.50 & 4.43 \\
\hline \multirow{4}{*}{ With application } & $2: 1: 0$ & 1.37 & 1.93 & 3.30 \\
\hline & 3:1:0 & 1.9 & 2.20 & 4.17 \\
\hline & $1: 1: 1$ & 1.00 & 1.80 & 2.80 \\
\hline & $2: 1: 1$ & 1.00 & 2.00 & 3.00 \\
\hline \multirow{3}{*}{ LSD (0.05) } & $3: 1: 1$ & 1.07 & 1.50 & 2.57 \\
\hline & & 0.47 & 0.59 & 0.96 \\
\hline & & \multicolumn{3}{|c|}{2015 season } \\
\hline \multirow{6}{*}{ Without application } & 1:1:0 & 0.09 & 0.16 & 0.24 \\
\hline & $2: 1: 0$ & 0.11 & 0.15 & 0.26 \\
\hline & $3: 1: 0$ & 0.11 & 0.15 & 0.26 \\
\hline & 1:1:1 & 0.13 & 0.20 & 0.33 \\
\hline & $2: 1: 1$ & 0.15 & 0.16 & 0.30 \\
\hline & 3:1:1 & 0.15 & 0.16 & 0.34 \\
\hline \multirow{6}{*}{ With application } & 1:1:0 & 0.14 & 0.19 & 0.33 \\
\hline & 2:1:0 & 0.13 & 0.13 & 0.26 \\
\hline & 3:1:0 & 0.15 & 0.21 & 0.36 \\
\hline & 1:1:1 & 0.12 & 0.15 & 0.26 \\
\hline & 2:1:1 & 0.17 & 0.20 & 0.37 \\
\hline & $3: 1: 1$ & 0.19 & 0.17 & 0.36 \\
\hline LSD (0.05) & & 0.04 & 0.05 & 0.07 \\
\hline
\end{tabular}


Table 11. Effect of mineral nitrogen fertilizer on the growth analyses of eggplant transplants at 60 days from seed sowing during 2015 season

\begin{tabular}{lccc}
\hline Mineral nitrogen fertilizer & \multicolumn{3}{c}{ Growth analyses } \\
\cline { 2 - 4 } & $\begin{array}{c}\text { Fresh/dry } \\
\text { weight ratio }\end{array}$ & $\begin{array}{c}\text { Root/ plant dry } \\
\text { weight ratio }\end{array}$ & $\begin{array}{c}\text { Shoot/ root dry } \\
\text { weight ratio }\end{array}$ \\
\hline Without application & 5.16 & 0.73 & 1.40 \\
With application & 4.15 & 0.88 & 1.19 \\
LSD (0.05) & $\mathbf{0 . 7 5}$ & $\mathbf{0 . 0 5}$ & $\mathbf{0 . 1 1}$ \\
\hline
\end{tabular}

Table 12. Effect of the culture media on growth analyses of eggplant transplants at 60 days from seed sowing during 2015 season

\begin{tabular}{lccc}
\hline Culture media & \multicolumn{3}{c}{ Growth analyses } \\
\cline { 2 - 4 } Peat moss :Vermiculite :Compost $(\boldsymbol{V} / \boldsymbol{V} / \boldsymbol{V})$ & $\begin{array}{c}\text { Fresh/dry } \\
\text { weight ratio }\end{array}$ & $\begin{array}{c}\text { Root/ plant } \\
\text { dry weight ratio }\end{array}$ & $\begin{array}{c}\text { Shoot/ root dry } \\
\text { weight ratio }\end{array}$ \\
\hline & & & \\
$\mathbf{1 : 1 : 0}$ & 4.97 & 0.66 & 1.55 \\
$\mathbf{2 : 1 : 0}$ & 3.58 & 0.91 & 1.23 \\
$\mathbf{3 : 1 : 0}$ & 5.21 & 0.73 & 1.37 \\
$\mathbf{1 : 1 : 1}$ & 4.56 & 0.73 & 1.38 \\
$\mathbf{2 : 1 : 1}$ & 4.46 & 0.87 & 1.16 \\
$\mathbf{3 : 1 : 1}$ & 5.16 & 0.97 & 1.07 \\
LSD $(\mathbf{0 . 0 5})$ & 0.86 & 0.23 & 0.26 \\
\hline
\end{tabular}

Table 13. Effect of the interaction between mineral nitrogen fertilizer and the culture media on the growth analyses of eggplant transplants at 60 days from seed sowing during 2015 season

\begin{tabular}{|c|c|c|c|c|}
\hline \multirow{2}{*}{$\begin{array}{l}\text { Mineral nitrogen } \\
\text { fertilizer }\end{array}$} & \multirow{2}{*}{$\begin{array}{c}\text { Culture media } \\
\text { Peat moss : Vermiculite : } \\
\text { Compost }(V / V / V) \\
\end{array}$} & \multicolumn{3}{|c|}{ Growth analyses } \\
\hline & & $\begin{array}{c}\text { Fresh/dry } \\
\text { weight ratio }\end{array}$ & $\begin{array}{c}\text { Root/ plant dry } \\
\text { weight ratio }\end{array}$ & $\begin{array}{c}\text { Shoot/ root dry } \\
\text { weight ratio }\end{array}$ \\
\hline \multirow[t]{8}{*}{ Without application } & 1:1:0 & 5.34 & 0.55 & 1.81 \\
\hline & 2:1:0 & 4.13 & 0.76 & 1.37 \\
\hline & 3:1:0 & 6.35 & 0.73 & 1.36 \\
\hline & 1:1:1 & 5.70 & 0.66 & 1.50 \\
\hline & 2:1:1 & 4.04 & 0.93 & 1.07 \\
\hline & 3:1:1 & 5.42 & 0.77 & 1.29 \\
\hline & 1:1:0 & 4.61 & 0.76 & 1.30 \\
\hline & 2:1:0 & 3.02 & 1.05 & 1.10 \\
\hline \multirow{4}{*}{ With application } & 3:1:0 & 4.07 & 0.72 & 1.37 \\
\hline & 1:1:1 & 3.42 & 0.79 & 1.26 \\
\hline & 2:1:1 & 4.87 & 0.82 & 1.24 \\
\hline & 3:1:1 & 4.91 & 1.16 & 0.85 \\
\hline LSD (0.05) & & 1.22 & 0.32 & 0.37 \\
\hline
\end{tabular}


and shoot/root dry weight ratio (Sw/Rw) characters, as compared with the other interaction treatments in this respect. On the other hand, using the culture media treatment of peat moss + vermiculite + compost at a ratio of $3: 1: 1(V / V / V)$, respectively with application of mineral nitrogen fertilizers came in the first rank and recorded significant effect on root/ plant dry weight ratio $(\mathrm{Rw} / \mathrm{Pw})$ character, as compared to the other interaction treatments. These results are going in agreement with those reported by Grazia et al. (2007) on sweet paper transplants.

\section{Chemical Composition of Transplants}

\section{Effect of mineral nitrogen fertilizer}

It is obvious from the presented results in Table 14 that, application of mineral nitrogen fertilizer to the culture media exerted a marked and significant effect on the chemical composition of eggplant transplants, expressed as the percentage of $\mathrm{N}, \mathrm{P}, \mathrm{K}$ and total carbohydrates at 60 days from seed sowing during 2015 season. While, the lowest values in this respect were more distinct without application of mineral nitrogen fertilizer.

The superior effect of application mineral nitrogen fertilizer on the chemical composition of eggplant transplants owing directly to the role of nitrogen in the plant. In this connection, Russell (1978), Bidwell (1979), Edmond et al. (1981), Mengle and Kirkby (1987) and Marschner (1995) concluded that nitrogen is an indispensable elementary constituent of numerous organic compounds of general importance (amino acids, protein, nucleic acids) and it is needed in formation of protoplasm.

Furthermore, the favorable effect of application mineral nitrogen fertilizer to the culture media on the chemical composition of eggplant transplant might be due to its biochemical associations in the transplants, utilization of metabolites and translocation of energy compounds.

On the other hand, the favorable effect of application mineral nitrogen fertilizer on building and accumulation of carbohydrates might be due to increasing the activity of carbohydrates hydrolyzing enzymes (Bidwell, 1979; Mengle and Kirkby, 1987).

In this regarded, El-Araby et al. (2003) on strawberry transplants, Baddour (2010) and Dawa et al. (2013) on tomato came to similar conclusion.

\section{Effect of the culture media}

The presented results in Table 15 show that, the maximum values of nitrogen (\%), phosphorus (\%) and total carbohydrates were recorded via using the culture media treatment of peat moss + vermiculite + compost at a ratio of 2:1:1 $(V / V / V)$. While, using the same components at a ratio of $3: 1: 1 \quad(V / V / V)$, respectively, being the superior treatment for increasing the percentage of potassium (\%) in the tissues of eggplant transplants with no significant differences between treatments in this respect.

From the above mentioned results, it could be suggested that the chemical composition of eggplant transplant significantly affected by the tested treatments of cultures media, while such effect varied greatly regarding to the ratio of the components of the culture media.

These results are in harmony with those reported by Riberio et al. (2007) on tomato transplants and Soliman (2010) on eggplant transplants.

\section{Effect of the interaction}

The recorded results in Table 16 indicate that, the interaction treatments between the two factors of study (the culture media and mineral nitrogen fertilizer) caused a marked and significant effect on the chemical composition of eggplant transplants. In addition, the maximum concentration of both $\mathrm{N}, \mathrm{P}, \mathrm{K}$ and total carbohydrates (\%) were more achieved via the interaction between application of mineral nitrogen fertilizer and the culture media which contained of peat moss + vermiculite + compost at a ratio of 3:1:0 $(V / V / V)$, respectively. These results are going in agreement with those reported by Mahmoud et al. (2014) on tomato transplants. 
Table 14. Effect of mineral nitrogen fertilizer on the chemical composition of eggplant transplants at 60 days from seed sowing during 2015 season

\begin{tabular}{lcccc}
\hline Mineral nitrogen fertilizer & \multicolumn{4}{c}{ Chemical composition (\%) } \\
\cline { 2 - 5 } & N & P & K & $\begin{array}{c}\text { Total } \\
\text { carbohydrates }\end{array}$ \\
\hline Without application & 2.91 & 0.137 & 4.52 & 18.24 \\
With application & 3.26 & 0.164 & 4.90 & 19.07 \\
LSD (0.05) & 0.01 & 0.003 & 0.002 & 0.30 \\
\hline
\end{tabular}

Table 15. Effect of the culture media on the chemical composition of eggplant transplants at 60 days from seed sowing during 2015 season

\begin{tabular}{|c|c|c|c|c|}
\hline \multirow{2}{*}{$\begin{array}{l}\text { Culture media } \\
\text { Peat moss :Vermiculite :Compost }(V / V / V)\end{array}$} & \multicolumn{4}{|c|}{ Chemical composition (\%) } \\
\hline & $\mathbf{N}$ & $\mathbf{P}$ & $\mathbf{K}$ & $\begin{array}{c}\text { Total } \\
\text { carbohydrates }\end{array}$ \\
\hline 1:1:0 & 2.38 & 0.126 & 4.58 & 17.66 \\
\hline 2:1:0 & 2.44 & 0.125 & 4.62 & 17.81 \\
\hline 3:1:0 & 3.14 & 0.157 & 4.70 & 18.92 \\
\hline 1:1:1 & 3.48 & 0.159 & 4.73 & 19.10 \\
\hline 2:1:1 & 3.65 & 0.173 & 4.79 & 19.41 \\
\hline 3:1:1 & 3.41 & 0.164 & 4.83 & 19.03 \\
\hline LSD (0.05) & 0.48 & 0.019 & 0.10 & 0.77 \\
\hline
\end{tabular}

Table 16. Effect of the interaction between mineral nitrogen fertilizer and the culture media on the chemical composition of eggplant transplants at 60 days from seed sowing during 2015 season

\begin{tabular}{lccccc}
\hline Mineral nitrogen fertilizer & $\begin{array}{c}\text { Culture media } \\
\text { Peat moss : Vermiculite } \\
\text { Compost }(\boldsymbol{V} / \boldsymbol{V} / \boldsymbol{V})\end{array}$ & $\mathbf{N}$ & $\mathbf{P}$ & $\mathbf{K}$ & $\begin{array}{c}\text { Total } \\
\text { carbohydrates }\end{array}$ \\
\hline & $\mathbf{1 : 1 : 0}$ & 2.16 & 0.117 & 4.34 & 17.28 \\
& $\mathbf{2 : 1 : 0}$ & 2.24 & 0.118 & 4.39 & 17.57 \\
Without application & $\mathbf{3 : 1 : 0}$ & 2.39 & 0.124 & 4.46 & 17.75 \\
& $\mathbf{1 : 1 : 1}$ & 3.48 & 0.144 & 4.54 & 18.65 \\
& $\mathbf{2 : 1 : 1}$ & 3.55 & 0.152 & 4.68 & 18.97 \\
& $\mathbf{3 : 1 : 1}$ & 3.65 & 0.168 & 4.72 & 19.22 \\
& $\mathbf{1 : 1 : 0}$ & 2.60 & 0.134 & 4.82 & 18.04 \\
With application & $\mathbf{2 : 1 : 0}$ & 2.64 & 0.132 & 4.85 & 18.05 \\
& $\mathbf{3 : 1 : 0}$ & 3.88 & 0.189 & 4.95 & 20.09 \\
& $\mathbf{1 : 1 : 1}$ & 3.48 & 0.174 & 4.92 & 19.56 \\
LSD (0.05) & $\mathbf{2 : 1 : 1}$ & 3.75 & 0.194 & 4.90 & 19.84 \\
& $\mathbf{3 : 1 : 1}$ & 3.19 & 0.159 & 4.94 & 18.84 \\
& & 0.68 & 0.028 & 0.15 & 1.09 \\
\hline
\end{tabular}




\section{REFERENCES}

Abad, M., F. Fornes, C. Carrión, V. Noguera, P. Noguera, A. Maquieira and R. Puchades (2005). Physical properties of various coconut coir dusts compared to peat. Hort. Sci., 40 (7): 2138- 2143.

Alam, M.K., M.A. Rahim, M.D. Rahman and M.D. Jahiruddin (2014). Effects of organic fertilizers on the seed germination and seedling vigour of tomato. Proc. the $4^{\text {th }}$ ISOFAR Scientific Conf. 'Building Organic Bridges', at the Organic World Congress, Istanbul, Turkey, 49-52.

Angadi, V., P.K. Rai and B.M. Bara (2017). Effect of organic manures and biofertilizers on plant growth, seed yield and seedling characteristics in tomato (Lycopersicon esculentum Mill.). J. Pharm. and Phytochem., 6 (3): 807-810.

Arenas, M., C.S. Vavrina, J.A. Cornell, E.A. Hanlon and J. Hochmuth (2002). Coir as an alternative to peat in media for tomato transplant production. Hort. Sci., 37 (2): 309312.

Augustinus, I.A.S. (2007). Nutrient release and availability from individual and blended nutrient sources for organic transplant production. M. Sc. Thesis, Florida Univ., USA.

Baddour, A.G. (2010). Effect of bio-fertilization on growth and productivity of tomato plant. M.Sc. Thesis. Fac. Agric. Mansoura. Univ., Egypt.

Badran, N.M., O.H. El-Hussieny and E.H. Allam (2007). Efficiency of some natural sustitutes of peat moss as growing media for tomato seedlings production. Aust. J. Basic and Appl. Sci., 1 (3): 193-207.

Bi, J., C. Li, Z. Zheng and L. Guo (2008). Effects of different strains from bacteria manure on growth of cucumber and tomato transplants. J. Qingdao Agric. Univ., Nat. Sci., 2 : 144.

Bidwell, R.G.S. (1979). Plant phyiology. $2^{\text {nd }}$ Ed. Mac Millan Publishing Co., INC. New York.

Botrini, L., G. Magnani, A. Graifenberg and L. Marchetti (2006). The organic production of tomato transplants. Colture-Protette, 35 (3): 77-84.

Bremner, J.M. and C.S. Mulvaney (1982). Nitrogen-total. Methods of soil analysis. Part 2. Chemical and microbiological properties, (methods of soil analysis), 2: 595-624.

Danaher, J.J., J.M. Pickens, J.L. Sibley, J.A. Chappell, T.R. Hanson and C.E. Boyd (2016). Tomato seedling growth response to different water sources and a substrate partially replaced with dewatered aquaculture effluent. Int. J. Recycling of Organic Waste in Agric., 5 (1): 25-32.

Dawa, K.A., T.M. Al-Gazar and A.M. AbdelFatah (2013). Effect of chicken manure combined with bio-fertilizers, mineral fertilizer and some foliar applications on: 1Vegetative growth and some chemical constituents of tomato leaves. J. Plant Prod., Mansoura Univ., 4 (10): 1555 - 1570.

Dubois, M., K.A. Gilles, J.K. Hamilton, P.T. Rebers and F. Smith, (1956). Colorimetric method for determination of sugars and related substances. Analyt. Chem., 28 (3): $350-356$.

Duncan, D.B. (1958). Multiple Range and Multiple F-Test. Biomet., 11:1-42.

Edmond, J.B., T.L. Senn, F.S. Znderws and R.G. Halfacre (1981). Fundamentals of Horticulture., Published by Tata McGrawHill Publishing Co., Limited, Indian.

Ekinci, M., M. Turan, E. Yildirim, A.Güneş, R. Kotan and A. Dursun (2014). Effect of plant growth promoting rhizobacteria on growth, nutrient, organic acid, amino acid and hormone content of cauliflower (Brassica oleracea L. var. botrytis) transplants. Acta Sci. Pol., Hortorum Cultus., 13(6): 71-85.

El-Araby, S.M., I.M. Ghoneim, A.I. Shehata and R.A. Mohamed (2003). Effects of nitrogen, organic manure and biofertilizer applications on strawberry plants. I-Vegetative growth, flowering and chemical constituents of leaves. J. Agric. and Env. Sci. Alex. Univ., Egypt, 2 (2):36- 62.

El-Beltagy, M.S., O.N. Sawan, S.A. Mohamedian, A.S. El-Beltagy and M.A. Maksoud (1986). 
Effect of some soilless media on the growth of tomato transplants. Acta Hort., 190: 481.

Gama, P.B.S., L.B. Wani, P.W. Ragga and B.C. Misaka (2015). Effect of soil media on growth of tomato seedlings (lycopersicon esculantum L.) under nursery (Greenhouse) conditions. Inter. J. Agric. Res. Rev., 3 (10): 432-439.

Ghanbari M. and A. Aboutalebi (2009). Application of garden-compost as culture medium for production of vegetable transplant. $6^{\text {th }}$ Iranian Hort. Sci. Congress.

Grazia, J.D., A. Pablo and A. Chiesa (2007). The effect of substrates with compost and nitrogenous fertilization on photosynthesis, precocity and pepper (Capsicum annuum) yield. Cien. Inv. Agr., 34(3): 151-160.

Hashemimajd, K., M. Kalbasi, A. Golchin, H. Knicker, H. Shariatmadari and Y. RezaeiNejad (2006). Use of vermicompost produced from various solid wastes as potting media. Europ. J. Hort. Sci., 71(1):21-29.

Herrera, F., J.E. Castillo, A.F. Chica and L. Bellido (2008). Use of municipal solid waste compost (MSWC) as a growing medium in the nursery production of tomato plants. Bioresource-Technol., 99(2):287-296.

Hoza, G. (2000). The establishment of some correlation indices between the features of eggplant transplant and their culture substrata Proc. Romanian Acad. Series B. Chem., Life Sci. and Geosci., 2(1):95-98.

Ikiz, O., K. Abak, H.Y. Daşgan and I. Ortaş (2009). Effects of mycorrhizal inoculation in soilless culture on pepper plant growth. Acta Hort., 807: 533-540.

Indriyani, N.L.P., S. Hadiati and A. Soemargono (2011). The effect of planting medium on the growth of pineapple seedling. J. Agric. Bio. Sci., 6 (2): 43- 48.

Jackson, M.L. (1970). Soil Chemical Analysis Prentice Hall. Englewood Gliffs, N.J.

Kampf, A.N. and M. Jung (1991). The use of carbonized rice hulls as a horticultural substrate. Acta Hort., (294): 271-283.
Kokalis-Burelle N., C.S. Vavrina, M.S. Reddy and J.W. Kloepper (2003). Amendment of muskmelon and watermelon transplant media with plant growth promoting rhizobacteria: Effects on transplant quality, disease, and nematode resistance. Hort. Tech., 13 (3): 476-482.

Liptay, A., E.F. Bolton and V.A. Dirks (1982). A comparison of field seeded and transplanted tomatoes grown on a clay soil. Canada J. Plant Sci., 62 (2): 483-487.

Mahmoud, A.M.A., M M I. Afifi and M.A. ElHelaly (2014). Production of organic tomato transplants by using compost as alternative substrate for peat moss. Ame.-Eurasian J. Agric. and Environ. Sci., 14 (10): 1095-1104.

Marschner, H. (1995). Mineral Nutrition of Higher Plants. Academic Press Limited. Text Book, London, England.

Mathowa, T., N. Tshegofatso, W. Mojeremane, C. Matsuane, G M. Legwaila and O. Oagile (2016). Effect of commercial growing media on emergence, growth and development of tomato seedlings. Int. J. Agron. Agri. Res., 9 (1): 83-91.

Mengel, K. and E. A. Kirkby (1987). Principles of plant nutrition., International Potash Institute, P.O. Box., CH-3048 WorblaufenBern, Switzerland.

Neamati H., M. Mehrbakhsh and J. Fallahi (2010). Study the effects of culture medium and irrigation regime on growth properties of tomato transplant. $2^{\text {nd }}$ Nat. Conf. on Agric. and Permanent Develop.

Olaria, M., J.F. Nebot, H. Molina, P. Troncho, L. Lapeña and E. Llorens (2016). Effect of different substrates for organic agriculture in seedling development of traditional species of Solanaceae. Spanish J. Agric. Res., 14 (1): 8001- 8013 .

Olsen, S.R., L.E. Sommers and A.L. Page (1982). Methods of soil analysis.Part 2.Chemical and microbiological properties of Phosphorus. ASA Monograph, 9: 403-430.

Peyvast, G.H., M. Noorizadeh, J. Hamidghli, K.P. Ramezani (2008). Effects of four different substrates on growth, yield and 
some fruit quality parameters of cucumber in bag culture. Acta Hort., 779: 535-540.

Radford, P.J. (1967). Growth analysis formula their use and abuse. Crop Sci., 7(3): 171-175.

Rahimi, Z., A. Aboutalebi and H. HasanZadeh (2013). Effect of various culture media on tomato transplant production. Int. Res. J. App. and Basic Sci., 4 (2): 326-328.

Rakesh, J. and P.V. Adarsh (2010). Effect of vermicompost on growth, yield and quality of tomato (Lycopersicum esculentum L.). Afr. J. Basic and Appl. Sci., 2 (3-4): 117123.

Ramteke, A.A., M.L. Narwade, A.B. Gurav, S.P. Chavan and A.G. Wandre (2013). Study of germination effect of fertilizers like urea, NPK and biozyme on some vegetable plants. Der Chemica Sinica, 4 (3): 22-26.

Reis, M. and L. Coelho (2007). Compost mixes as substrates for transplant production. Acta Hort., 747:283-291.

Ribeiro, H.M., A.M. Romero, H. Pereira, P. Borges, F. Cabral and E. Vasconcelos (2007). Evaluation of a compost obtained from forestry wastes and solid phase of pig slurry as expanded rice hull-based substrates J. Korean Soc. Hort. Sci., 41 (3): 249-253.

Russell, E.E. (1978). Soil Conditions and Plant Growth. $10^{\text {th }}$ Ed., Longman Group Limited, London.
Shahinrokhsar, P. and M. Tavusi (2008). Effect of different substrate on fruit yields and some quantitative parameters of strawberry (Rosaceae forgaria vesaca E. European) crops in soilless culture (Bag culture). Proc. Int. Symposium on Strategies Towards Sustainability of Protected Cultivation in Mild Winter Climate. Turkey. Antalia, 129.

Sharaf-Eldin, M.A., K.E. Peregi and Z. Pap (2015). Effects of different organic fertilizers on seedlings growth and photosynthesis of chinese cabbage (Brassica rapa ssp. pekinensis). Proc. $50^{\text {th }}$ Croatian and $10^{\text {th }}$ Int. Symposium on Agric. Opatija Croatia, 286290.

Snedecor, G.W. and W.G. Cochran (1980). Factorial Experiments. Statistical Methods, 7.

Soliman, F.M.A. (2010). The influence of different greenhouse transplants production systems on the growth and yield of some solanacys. M.Sc. Thesis, Fac. Agric. Damanhour Branch, Alex. Univ., Egypt.

Statistics of the Ministry of Agriculture (2014).

Unal, M. (2013). Effect of organic media on growth of vegetable seedling. Pak. J. Agri. Sci., 3: 517-522.

Zandi, M., S. Seyed-Maasumi and A. Hassanpour (2011). Evaluation and comparison of culture media for production of two greenhouse cucumber cultivars transplant. $1^{\text {st }}$ Spec. Conf. Agric. Dev. in Northwest provinces of Iran. 
Zagazig J. Agric. Res., Vol. 45 No. (1) 2018

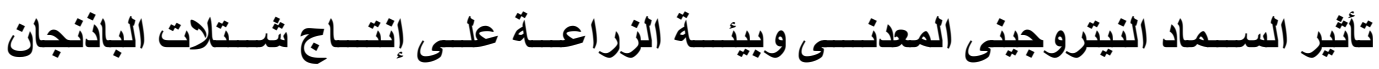

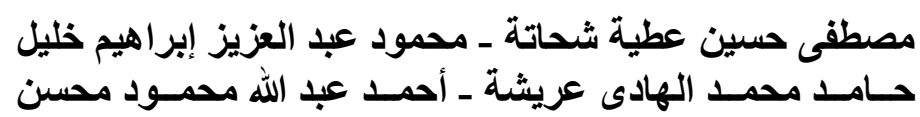

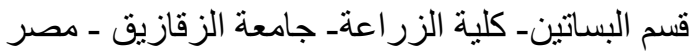

أجرى هذا البحث فى مشتل خاص تحت ظروف الصو الصوبات البلاستيكية، فى منطقة بلبيس- محافظة الثرقية (مصر)

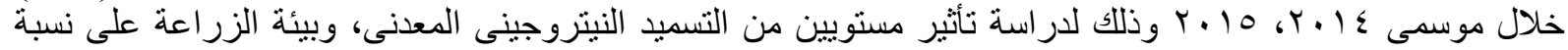

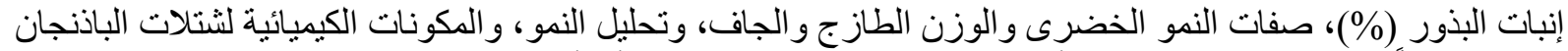

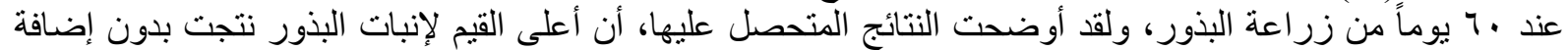

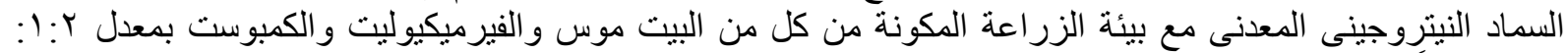

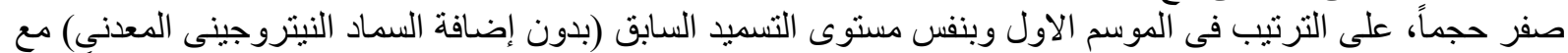

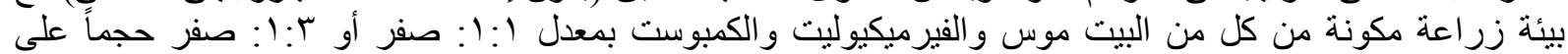

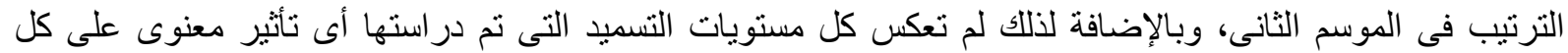

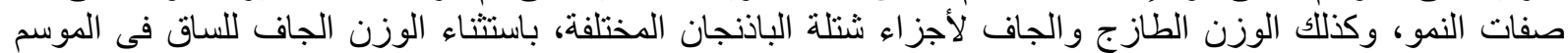

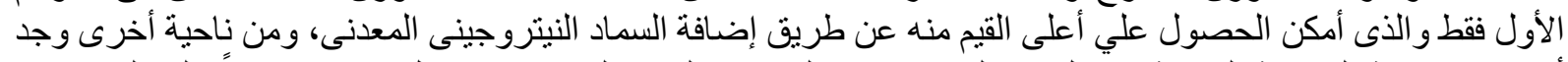

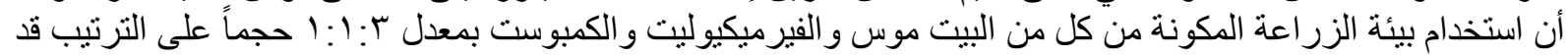

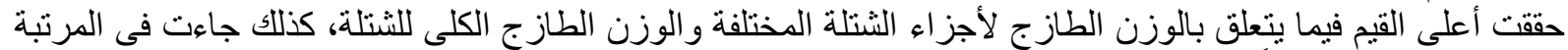

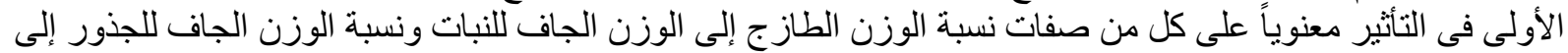

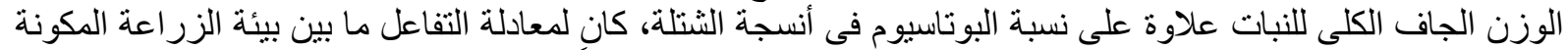

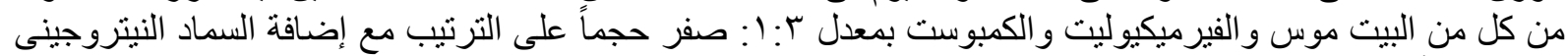

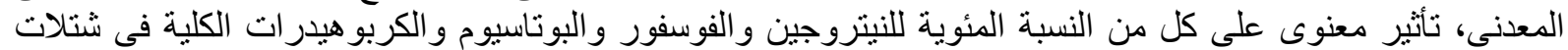

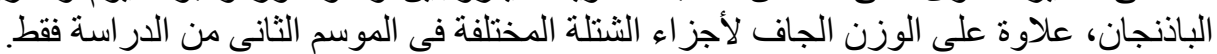

أستاذ الخضر المتفرغ - كلية التكنولوجيا والتنمية - جامعة الزقازيق. 